Volume 6 Issue 4, December 2019

Nationally Accredited Journal,

Decree No. B/4130/E5/E5.2.1/2019

\title{
Due Position to Legal Documents under the Hand in Notary Legalization
}

\begin{abstract}
Nur Amanah ${ }^{1}$, Achmad Sulchan ${ }^{2}$ and Jawade Hafidz ${ }^{3}$
Abstract. The purpose of this study was to investigate and analyze: 1) the position of the deed under hand on legalization by notary and 2) Due to legal documents under the hand that has been in Legalization by Notary. Based on the wording of Article 15 paragraph (2) a and b of Law No. 2 of 2014 on the Amendment of Act No. 30 of 2004 concerning Notary, the Notary in carrying out his authority to conduct the legalization of the deed under the hand. The method used in this study is a socio-juridical. The data in this study are primary data obtained from the field by means of interviews and secondary data consists of primary legal materials, secondary legal materials as well as materials law tertiary literature. Data were then analyzed qualitatively.

Based on the analysis, it can be seen that: 1). Position deed under the hand that was authorized by the Notary: when both parties recognize and explain correctly what is in deed under the hand, then the deed under the hand of a criminal offense and be perfect evidence as authentic deed. 2). The legal consequences deed under the hand which has been legalized by Notary: deed under hand on legalization by notary is not a legal effect of evidence which was perfect because they can be disputed later in court, and if the parties deny the strength of evidence in the hands of the judge's decision.
\end{abstract}

Keywords: Deed Under Hand; Notary; Legalization.

\section{Introduction}

Indonesia is a State of Law (rechstaat) as contained in the Constitution of the Republic of Indonesia Of 1945 which made it clear that the Republic of Indonesia is a State of Law, which guarantees the rule of law, order and protection of the core of truth and justice.

In Indonesia there are rules regarding the deed done before Notary or officials, but people prefer to make a deed under hand. This is done on the basis of trust between the parties, whose identity was mentioned in the deed under the hand.

One purpose of the certificate is in order to comply with the Act and the Regulations to obtain or ensure legal certainty of the occurrence of a legal event. Deed by Subekti is defined as an article that has been deliberately created to be used as evidence of an event and signed. ${ }^{4}$

Notary is a public official who is authorized to make authentic deeds and other authorities as stipulated in Law No. 30 of 2004 in Article 1 (1) following changes to new legislation, namely Law No. 2 of 2014 concerning amendments to the Act No. 30 of 2004 concerning Notary. The philosophical foundation in the shape of Law No. 30 of 2004 concerning Notary is to create legal certainty, order and legal protection that core truth and justice through the deed he had done, the Notary must be able to provide legal certainty to the user community Notary services. ${ }^{5}$

\footnotetext{
${ }^{1}$ Student Master of Notary Program, Faculty of Law, Sultan Agung Islamic University Semarang, email amanahnur22@gmail.com

2 Lecturer, Faculty of Law, Sultan Agung Islamic University Semarang

${ }^{3}$ Lecturer, Faculty of Law, Sultan Agung Islamic University Semarang

${ }^{4}$ Subekti, Law of Evidence,1995, Hukum Pembuktian, Jakarta: Pradya Paramitha, p. 25.

${ }^{5}$ Habieb Adjie, 2009, Meneropong Khasanah Notaris Dan PPAT Indonesia, Bandung: PT.Citra Aditya Bakti, p. 14.
} 
Authentic act is meant as an authority created by Notary useful for people who need the deed as a deed wills, power of attorney and so forth. The presence of the Notary as a public official is the answer to people's need legal certainty on every engagement is done, especially in terms of trade-related engagements, accounts payable and other engagement in public life.

Strength tied deed under the hand, according to Article 1875 BW, if the deed under the hand is recognized by the person against whom the deed was to be in use, then the deed is a means of proving perfect against those who signed are also heirs and those who get right away. ${ }^{6}$

Terms of the deed under the hand evidence, namely:

- Letter or writing was signed;

- The content be explained in it concerns the legal acts or legal relationships;

- Deliberately designed to be used as proof of the deed referred therein.7

Notary related tasks and authority was not limited to just create authentic act alone but can also create a Notary attestation letters under the counter and register are usually referred to by legalizing and make the copy of the deed and approved the copy of compatibility with the original letter.

The mistake often occurs in people to force of law between the deed under the hand that has been in legalizing with deed under the hand that has been legalized, because both contain the signature of a Notary. It becomes important to review that in the future there is no misunderstanding between the two.

In Article 15 paragraph (2) letter a Law Notary, in his post, authorities certify the signatures and set a firm date in the letter under the hand by enrolling in a special book. This regulation is the legalization of the deed under the hand that is made by a natural person, or by the parties on paper stamped with the registration in a special book provided by the Notary. In short, this is the point of legalizing the parties make the letter, brought to the Notary and signed before Notary, later recorded in the book Legalization. Date upon signing the Notary's why, as the date of the legal act that created rights and obligations between the parties.

Rank or legal force of a stronger legalization because by doing legalization then signing is done before a Notary. Because Notaries may provide and can ensure the signing date of the deed under the hand according to the meaning contained in Article 1874 of the Civil Code that "that is considered as a writing under the hand is a deed signed under hand, letters, lists, letters home affairs stairs and writings without the mediation of a public official. "

The existence of a Notary is needed by the community in order to provide legal certainty and to protect community rights of the parties are not responsible. In this study, the authors analyzed the associated notch deed under the hand that was authorized by notary and legal consequences deed under the hand that has been legalized by notary.

Based on the foregoing, the author intends to conduct a study entitled "The Position And Effects Deed Under Legalization By Hands On Notary"

\section{Research methods}

According Soerjono Soekanto, research is a scientific activity that is based on methods, systematic and specific rationale that aims to study one or more of the symptoms of certain laws by way of analyzing it. Besides, it is also held in-depth examination of the

\footnotetext{
${ }^{6}$ See Article 1875 Book of Civil Law Act.

7 Supomo, 1972, Hukum Acara Perdata Pengadilan Negeri, Jakarta: Pradnya Paramita, p.78.
} 
Volume 6 Issue 4, December 2019

Nationally Accredited Journal,

Decree No. B/4130/E5/E5.2.1/2019

facts of the law and then seek a solution to the problems arising in the relevant symptoms. ${ }^{8}$

The method used in this research is the socio-juridical, which is a study of the state or society with the intent and purpose of finding facts (fact-finding) and then identified (problem-identification) and eventually lead to the settlement of the problem (problemsolution).$^{9}$

This type of research is a kind of field research (Field Research). By way of interviews with informants. Sociological juridical research method chosen because it fits in with the purpose of study was to assess the status and the legal consequences under the deed in hand on legalization by notary.

\section{Results and Discussion}

\subsection{Position Deed Under Hands On Legalization By Notary}

In general, when the parties wish to perform a transaction or legal act will make an agreement in advance. It is very important to show that between these parties agree to bind themselves to one another in order to perform legal acts.

Based on the wording of Article 1 (1) of Law No. 2 of 2014 in Amendment Act No. 30 of 2004 concerning Notary that "the notary is a public official who is authorized to make the deed authentic and have the other authorities referred to in the Act or under the Act more "

Notary as a public official or public official would have the authority and each authority must be based on Rule of Law. Notaries have a great responsibility towards the services provided to public, particularly related to the deed of the Notary.

Notary authority pursuant to Article 15 paragraph (2) of Law No. 2 of 2014 concerning amendments to the Law No. 30 of 2004 concerning Notary. The philosophical foundation in the shape of Law No. 30 of 2004 concerning Notary, namely:

- Certify the signatures and set a firm date in the letter under the hand enrolled in a special book;

- Letters posted under the hand by enrolling in a special book;

- Make a copy (copy) the original of the letters under the hands of the copy that contains a description as written and illustrated in the letter in question;

- Doing attestation match between the photocopy with the original;

- Providing legal counseling in connection with the deed;

- A deed relating to land, or

- Make the minutes of the auction.

Based on the wording of Article 15 paragraph (2) of Law No. 2 of 2014 on the Amendment of Act No. 30 of 2004 concerning Notary, the Notary in carrying out his authority to conduct the legalization of the deed under the hand as it described in letters $b$ and $a$. Thus Notaries in running the office has the authority to legalize the deed under the hand, and the authority is protected Regulation Act. In terms of the deed under the hand Notary shall certify signatures and set a firm date of the letter / certificate under the hand.

Article 1874 of the Civil Code states that:"Which is regarded as the text below the hand is a certificate signed under hand, letters, lists, letters household affairs and other writings made without the mediation of a public official".

\footnotetext{
${ }^{8}$ Soerjono Soekanto, 1998, Pengantar Penelitian Hukum, Jakarta: UI Press, p.10.

${ }^{9}$ Roony Hanitjo Soemitro, 2008, Metode Penelitian Hukum Dan Yurimetri, Jakarta, p. 42.
} 
Regarding the legalization of Article 1874 of the Civil Code states:

"Writings under the hand is considered the deed signed under hand, papers, registers, letters household affairs and other posts made without the mediation of a public employee. By signing the writing under the hand equivalent of a thumbprint, spiked with a statement dated from a Notary or an employee of the other engaged by the Act where it turned out that he knew the thumbprint, or that this person had been introduced to him, that the deed it was explained to him, and that after that thumbprints affixed in front of the public servants. These officers must be posted on the text. With the Act can be held further rules on the said statements and bookkeeping "

From the wording of Article 1874 of the Civil Code mentioned above this legalization has meaning that writing under the hand in whatever form and the legal acts made and signed by the parties, and then be approved by the notary or other authorized officials.

In the Civil Code regarding the evidence in this paper settings can be seen in Section 1867-1894, where Article 1867 of the Civil Code states: Proof by writing done with authentic writings and the writings under the hand.

Regarding the procedure of legalization qualified by the sound of a Civil Code Article 1874:

- Signer certificates (the parties) in the know or be introduced to the Notary;

- Before the deed was signed, a notary must first be read out its contents;

- Then the deed signed before the Notary.

The contents of the deed under the hand of different construction date need to be legalized by a Notary upon agreement of the parties, then given the date and the parties sign it in the presence of a Notary. With the parties are guaranteed and legal certainty on the date, signature and identity of the parties.

Deed under hand Legalization is essentially to prove that the writings under the hand made by the parties was indeed made by the parties. Therefore, to prove the truth to be writing or deed under the hand then in need of validation performed in the presence of a Notary or other authorized officials. Notary witnessing the parties signed a deed under the hand and ensure the signing of the signatories date it took place or on the same day. ${ }^{10}$

\subsection{The legal consequences deed under hand on legalization by notary}

Notaries are General Authorities authorized to make an authentic deed of all deeds, agreements, and provisions required by legislation or desired by the stakeholders to be stated in an authentic deed, guaranteeing the creation date of the deed, saving certificates, giving copy and quote the deed, all of it throughout the making of the deed it not also be assigned or excluded to other officials or any other person specified by the Act. ${ }^{11}$

Notary as a public official has the authority to serve people who want to perform an act of law, particularly in the civil case. Legal services to more community at a given Notary public official in order to provide certainty and assurance to the parties to a legal act.

Some communities, there are still many who do not understand the importance of an important document on paper containing legal acts, in particular the lack of knowledge about authentic deed. To make an agreement, an agreement on a legal act, the public

\footnotetext{
${ }^{10}$ Results Interview with Zulaicha, Notary and PPAT, Semarang: December 9th, 2019.

${ }^{11}$ Article 15 of Law No. 2 of 2014 On Notary
} 
Volume 6 Issue 4, December 2019

Nationally Accredited Journal,

Decree No. B/4130/E5/E5.2.1/2019

is often only done on the basis of mutual trust and made orally. Where usually only watched by family or neighbors. Then, when there is a problem and need proof of truth, the document does not have a strong evidentiary tool. Various barriers to prove at disclaimed by one of the parties. Testimony related to deed under the hand has a weakness.

Written evidence in a civil case is very important. This will be very useful when there is a problem in the future or there are truth for the content of the certificate, the proof of the text will be the main evidence in the civil case.

The importance of written evidence is also described in the Qur'an. Al-Baqoroh (2): 282 which means that reads:

"O ye who believe, if you do not cash for the specified time you shall write them. And let a writer of you typed it correctly. And do not be reluctant writer to write as Allah has taught him, then let him write and let people who owe it to dictate (what is written it) and let him devoted to Allah his Lord. "

Most people are still much less aware of the need for a treaty or agreement made by the parties is made in an authentic severe. It is in need to obtain legal certainty and a strong evidence in case of problems later on.

In a civil case, the selection of cases, evidence has a very important role. Because in this stage in disputing parties the opportunity to tell about the facts or subterfuge related documents. By way present the facts in the proof is exactly through the stage of proof in civil proceedings in the court settlement then judges gave right decisions, fair and true.

Deed under the hand Legalization performed by a Notary is an admission related to determination of the date on forged deed under the hand and the signatures of the parties. With a deed in legalization by notary, the parties have gained legal certainty or have strong evidence. In this case all parties whose identity is not listed in the deed under the hand can not deny or say do not know the contents of the deed. Because the contents of the deed have been read or described before in doing a signatory to the parties before the Notary and witnessed by a Notary witnesses know. ${ }^{12}$

Deed under the hand that is as strong as an authentic deed, namely: ${ }^{13}$

- Deed under the hand that was authorized (Article 1874a BW);

- Letter recognition wholly unilateral debt of the debtor's own handwriting (Article 1878 BW) at least the amount of money with numbers and letters must debtor's own handwriting;

- Note that made creditor at a right reasons though no date and not initialed, should benefit the debtor.

In a related civil case judges proving highly in need of a means of proof, it is necessary for the judge to give the settlement or decision-making based on evidence presented by the parties.

Based on the above, the deed under hand on legalization that has been recognized can not be denied. Deed under the hand that has met the formal requirements and material requirements then the deed has had the perfect proof and binding. But a deed under the hand can still be contested in court if one of the parties submit other evidence of the contents and the signature or denied or admitted the truth. ${ }^{14}$

12 Op. Cit Zulaicha

13 Bambang Sugeng US, and Sujayadi, 2012, Pengantar Hukum Acara Perdata Dan Contoh Dokumen Litigasi Perkara Perdata, First Edition, Jakarta: Prenadamedia Group, Kencana, p. 68.

${ }^{14}$ Op. Cit, zulaicha. 
In contrast to the opinion of the Notary Typhoon ${ }^{15}$ who said that the deed under hand on legalization by notary it is binding only on the parties in the proof. Notaries are not involved as part of the deed under the hand. This is because the Notary not as parties. Notary simply validate the signature.

\section{Closing}

\subsection{Conclusion}

- Position Deed Under Hands On Legalization By Notary Legalization deed under hand by a Notary is an acknowledgment of the date of the deed under hand by the parties, so that the deed under the hand that has been in the legalization of certainty due to his legal for judges regarding the date, identity and signature of the parties to such agreements, when both parties recognize and explain correctly what is in deed under the hand, then the deed under the hand of a criminal offense and be perfect evidence as authentic act, and if the parties deny the strength of evidence in the hands of the judge's decision

- As a result of the Deed Law Under Hands On Legalization By Notary

Deed under the hand on legalization by notary is not a legal effect of evidence which was perfect because they can later on disputed in court. Deed under the hands of the legal consequences of proof power was in the hands of judges.

\subsection{Suggestion}

- Each will perform a treaty or agreement between the parties, be it family or anyone else should not merely verbal, should make before the Notary, in order to have a perfect legal effect of evidence.

- With the authentic deed made by or before a Notary, this will be very helpful in the future judge considered if there is a dispute.

\section{References}

[1] Adjie Habieb, 2009, Meneropong Khasanah Notaris Dan PPAT Indonesia, Bandung: PT.Citra Aditya Bakti.

[2] Bambang Sugeng US, and Sujayadi, 2012, Pengantar Hukum Acara Perdata Dan Contoh Dokumen Litigasi Perkara Perdata, First Edition, Jakarta: Prenadamedia Group, Kencana

[3] Hanitjo Roony Soemitro, 2008, Metode Penelitian Hukum Dan Yurimetri, Jakarta

[4] Supomo, 1972, Hukum Acara Perdata Pengadilan Negeri, Jakarta: Pradnya Paramita

[5] Soekanto Soerjono, 1998, Pengantar Penelitian Hukum, Jakarta: UI Press

[6] Soerjono Soekanto and Solemanb. Taneko, 2001, Hukum Adat Indonesia, Jakarta: Raja Grafindo Persada

[7] Subekti, 1995, Hukum Pembuktian, Jakarta: Pradya Paramitha

[8] Constitution of the Republic of Indonesia Of 1945.

[9] Law Number 30 Of 2004 on Notary.

[10] Law No. 2 of 2014 on the Amendment of Law Number 30 Of 2004 on Notary.

[11] Code of Civil law.

${ }^{15}$ Interview with Taufan F. Riyanto, Notary and PPAT, Semarang: December 7th, 2019. 